\title{
Protecting labor rights in preferential trade agreements: The role of trade unions, left governments, and skilled labor
}

\author{
Damian Raess $^{1,2}$ (D) Andreas Dür ${ }^{3} \cdot$ Dora Sari $^{4,5}$ \\ Published online: 6 March 2018 \\ C The Author(s) 2018. This article is an open access publication
}

\begin{abstract}
This paper investigates variation in the design of labor provisions in preferential trade agreements (PTAs) by focusing on the power of trade unions, the role of government partisanship, and the relative strength of skilled labor. We expect strong trade unions and leftleaning governments to be associated with more, and more far-reaching labor provisions in PTAs. We also expect the strength of skilled workers relative to the strength of unskilled workers to negatively correlate with the depth of labor provisions in PTAs. In addition, the effect of trade unions should be conditional on both the presence of left government and democracy. We test these hypotheses relying on an original dataset of labor provisions included in 483 PTAs signed between 1990 and 2016. This dataset covers 140 different labor provisions that relate to six overarching dimensions. The quantitative analysis finds
\end{abstract}

Electronic supplementary material The online version of this article (https://doi.org/10.1007/s11558-0189301-z) contains supplementary material, which is available to authorized users.

\section{Damian Raess}

damian.raess@wti.org; d.raess@reading.ac.uk

Andreas Dür

andreas.duer@sbg.ac.at

Dora Sari

dora.sari@etu.unige.ch; dsari@law.harvard.edu

1 World Trade Institute, University of Bern, Hallerstrasse 6, 3012 Bern, Switzerland

2 School of Politics, Economics and International Relations, University of Reading, Whiteknights Campus, Reading RG6 6AA, UK

3 Department of Political Science and Sociology, University of Salzburg, Rudolfskai 42, 5020 Salzburg, Austria

4 Department of Political Science and International Relations, University of Geneva, Boulevard du Pont d'Arve 40, 1211 Genève, Switzerland

5 Labor and Worklife Program, Harvard Law School, 8 Mt. Auburn Street, 02138 Cambridge, MA, Switzerland 
support for the expectations concerning the influence of trade unions and the role of a country's skill profile.

Keywords Design of international institutions · Preferential trade agreements · Labor provisions $\cdot$ Non-trade issues $\cdot$ Human rights

\section{Introduction}

Many of the preferential trade agreements (PTAs) signed over the past twenty years include labor provisions (LPs). ${ }^{1}$ These LPs link the benefits of better market access to, for example, the enforcement of internationally recognized worker rights. But much variation remains across PTAs with respect to the scope and stringency of these LPs (International Labour Organisation 2013; 2016). Some PTAs include far-reaching and highly enforceable LPs, while others only make fleeting references to labor standards or even fully omit the topic. What explains variation in the extent to which labor standards are covered by PTAs?

As will be demonstrated below, in spite of the rapidly growing literature on the design of PTAs, the investigation of such questions in relation to LPs in PTAs has largely remained an uncharted territory. To fill this gap, our paper looks at domestic factors that determine the inclusion of and variation in the design of LPs in PTAs. In particular, we argue that trade union power and government ideology affect the presence and depth of such provisions. We also argue that there is heterogeneity in the preferences of workers over LPs in PTAs.

Our analysis relies on a new database. As part of a larger project, we have systematically documented the design of LPs in PTAs (LABPTA database; Raess and Sari 2017). The database contains 483 PTAs coming from the DESTA database (Dür et al. 2014), the most comprehensive in terms of the number of such agreements covered. Our coding table consists of 140 items and distinguishes between six overarching categories, namely preambular provisions on aspirational labor commitments, substantive commitments on LPs, obligations in relation to LPs, enforceability of the substantive LPs, cooperation over labor issues, and the institutions set-up to implement the labor-related commitments. The coding achieves a high level of granularity, thereby allowing a fine-grained analysis of the politics of the trade-labor linkage in PTAs.

We find that stronger trade unions are associated with more far-reaching LPs in PTAs. As the strength of skilled workers increases relative to the strength of non-skilled workers, however, the depth of LPs in PTAs declines. We do not find a direct relationship between left governments and the depth of LPs in PTAs. However, we do find that the effect of the strength of trade unions is conditional on both the presence of left governments and regime type. Strong trade unions and left governments together go hand in hand with deeper labor protection provisions in PTAs. The strength of trade unions also matters more for the design of LPs in PTAs if they try to influence a democratic government than if they need to convince a non-democratic government. Overall, these findings offer strong support for our argument about the impact of domestic factors on the design of LPs in PTAs.

\footnotetext{
${ }^{1}$ Preferential trade agreements are agreements liberalizing trade between two or more countries without extending this liberalization to all countries.
} 


\section{Literature review}

The significant increase in the number of PTAs and the variation in their content have attracted considerable scholarly attention over the past decades with the purpose of better understanding why countries sign PTAs, what explains variation in their design and how effective PTAs are in changing domestic laws and institutions (Dür and Elsig 2015). A large amount of literature exists on why PTAs form and expand and why states might elect to engage in PTAs.

Only in recent years have an increasing number of studies started to analyze the factors explaining variation in the content of PTAs (e.g., Kucik 2012; Smith 2000). A key contribution in this regard is the Design of Trade Agreements (DESTA) database collecting PTA design data over time (Dür et al. 2014). Benefiting from the dataset, Baccini et al. (2015) argue and empirically show that in designing new PTAs, countries tend to imitate existing PTAs: they can choose among one of three PTA templates, namely a narrow and shallow agreement, an EU-type agreement, or a NAFTA-type agreement.

As to human and social rights provisions in PTAs, scholars have been interested in their effects, focusing on environmental performance (Baghdadi et al. 2013) or human rights violations (Hafner-Burton 2005; Spilker and Böhmelt 2013). Alongside a number of qualitative studies (e.g., ILO 2013, 2016; Giumelli and van Roozendaal 2017; Orbie et al. 2017), a recent but growing literature has begun to address the impact of LPs in PTAs (Kim 2012; Postnikov and Bastiaens 2014; Kamata 2016).

The causes and motivations that might explain the inclusion and variation of LPs in PTAs have so far generated much less attention. Early research suggested that labor standards in PTAs serve protectionist purposes (Bhagwati 1995; for an early rebuttal, see Elliott and Freeman 2003: ch. 4). Hafner-Burton (2009) emphasized domestic pressures from citizen groups and labor unions that make governments include human rights provisions in PTAs when interests between civil society groups and policymakers are aligned. The bulk of the literature, however, focuses on the broad differences between American and European approaches to the trade-labor linkage. While Kerremans and Gistelinck (2009) look at the aggregative role of political parties, Hafner-Burton (2009) focuses on veto players. Adriaensen and González-Garibay (2013) found that the EU's decisions have also been shaped by the perceptions and market power of negotiating partners.

Recently, scholars have started to explain the design of non-trade issues (NTIs) in PTAs using quantitative analyses. Focusing on the differences in the domestic characteristics of the trade partner countries, Lechner (2016) found that strong import pressure from the partner country and a large difference in wage levels are associated with more stringent social and environmental provisions in PTAs, while a large difference in civil and political rights protection levels between signatory countries leads to more farreaching human rights provisions only where one member complies at a high level of protection. Milewicz et al. (2016) examine the proliferation of PTAs with NTIs encompassing human rights, labor rights, environment, corruption, security and democracy provisions. Testing rival arguments about mutual commitments (i.e., shared values), power relations, and cost considerations, the authors find that cost-based network effects are the principal factor explaining the spread of NTIs.

Our paper makes three main contributions. First, it is the first study that systematically investigates the relationships between domestic factors and variation in the 
design of LPs in PTAs. Previous studies have either used qualitative methods, preventing generalization across time and space, or focused on NTIs more broadly. It is not clear a priori, however, that the determinants of labor and, for instance, environmental provisions are identical. There is much to gain analytically in (further) disaggregating NTIs. Second, to our knowledge, our LABPTA dataset (Raess and Sari 2017) is the most comprehensive coding of LPs in PTAs, thereby allowing for more finegrained analysis of the variation in the design of LPs in PTAs. Our outcome variable reflects our detailed and nuanced coding. Finally, our paper is the first to directly test the role of skilled labor, trade unions and of their ally in government in the politics of the trade-labor linkage. We focus on (skilled labor), trade unions, and left government because they are the "usual suspects" when it comes to the protection of labor standards, particularly domestic labor regulation (see below). Whether their influence carries over to the international sphere in the area of the trade-labor linkage is an open question.

\section{The argument}

In spite of the decline of organized labor and the weakening of the relationship between trade unions and left parties (Western 1997; Howell 2001), trade unions remain the most relevant societal actors when it comes to the promotion and protection of workers' rights and conditions at work. With the advent of industrial capitalism, workers organized in trade unions sought to loosen their status as pure commodity. By aggregating the interests of workers and increasing their bargaining power relative to employers, trade unions have successfully entered into collective bargaining at various levels to improve workers' living standards and employment conditions. They have also sought the (public) provision of social welfare programs such as unemployment insurance and employment protection legislation to protect workers against the vagaries of the market. The power of trade unions, however, crucially depends on their ability to exert a monopoly over the labor supply. When push comes to shove, powerful trade unions are capable to withdraw labor supply by way of industrial action, thereby disrupting the economy and threatening the viability of hostile regulation by right- and left-leaning governments alike. Encompassing labor unions, characterized by high trade union membership, have a greater monopoly over labor supply and thus tend to be associated with more political clout.

Economic globalization, fueled inter alia by government decisions to sign PTAs, generates winners and losers and economic insecurities for all (Rodrik 1997; Scheve and Slaughter 2004. In advanced economies vulnerable workers championed by labor unions have demanded and obtained domestic compensatory policies to offset greater exposure to external risks (Cameron 1978; Katzenstein 1985). Trade unions have been the staunchest advocates of the protection of domestic labor standards in the face of adversarial political and economic forces, and have demanded the expansion of welfare programs that address the needs of globalization losers such as trade-adjustment assistance (Burgoon and Hiscox 2000).

With the deepening of globalization, trade unions in advanced economies have also increasingly sought to protect labor standards at regional and international levels. In Europe, they have pushed for the establishment of European works councils, while at the global level they have sought international framework agreements concluded 
between global unions and multinational enterprises. While the campaign for a social clause at the multilateral level ultimately failed in the 1990s, not least due to the opposition of trade unions in developing countries such as India (Van Roozendaal 2002), trade unions in the US, Canada and in Europe have since lobbied their governments to include LPs in their bilateral or regional PTAs.

Although skepticism about trade agreements and LPs included in those continues to run deep among the labor movements in developing countries, a slow shift can nevertheless be detected in how such provisions are seen by them. As recent scholarship has shown, trade unions in the Global South may exert influence on the functioning of international organizations. Regarding lending decisions by the International Monetary Fund, countries with stronger domestic labor receive less intrusive laborrelated conditions in loan agreements (Caraway et al. 2012). Cognizant of their potential power in influencing international decisions, trade unions in developing countries have gradually become less opposed and in some instances even supportive of social clauses (Park 2014) as a possible means in the fight for the protection of basic labor rights and better labor conditions.

Besides, the rise of labor transnationalism has the potential to build up labor strength in developing countries and to ratchet up labor standards globally, as well as to socialize developing country trade unions to the norms of internationally recognized labor standards and the desirability of social clauses. On the one hand, labor groups in the context of a closed domestic political opportunity structure face incentives to "go transnational." As formulated in the well-known "boomerang effect" by Keck and Sikkink (1998), local groups that cannot achieve their objectives in the domestic political arena link up with actors beyond borders to promote change at home. Where the prospect for domestic labor improvements is blocked, trade unions may find it attractive to team up with unions elsewhere in search for international regulation that increases the incentives and/or pressures on the state to protect and promote labor standards. Enforceable labor standards in PTAs can constitute one such tool. However, a pre-condition for labor transnationalism may well be a modicum of initial organizational and financial resources. Also, the presence of progressive, left-leaning trade unions increases the likelihood that transnational collaboration will form (Anner 2011; Kay 2011).

On the other hand, trade unions in the North play an increasingly active role in helping workers in the Global South to attain safe and healthy workplaces and greater equity at work. For instance, the AFL-CIO, one of the strongest proponents of enforceable labor standards in PTAs, has in partnership with the Solidarity Center and the global labor movement been monitoring how effectively trade partners ensure respect of labor rights. The Solidarity Center is a US-based international worker rights organization that works with trade unions, worker associations and community groups across the globe to promote collective labor rights. As such it is plausible to argue that the Center acts as a transmission belt in developing countries, helping to socialize reluctant trade unions into the idea of formal trade-labor linkage.

In short, to counteract the increasing insecurities and inequalities generated by globalization, trade unions take on a pivotal role to defend workers' protections, including at the international level. Hence our first hypothesis:

- Hypothesis 1 (Labor power): Stronger trade unions in at least one member country of a PTA are associated with far-reaching labor provisions in that PTA. 
A second proposition regarding the power and preferences of domestic actors concerns the role of left-wing parties. As documented by a vast literature in political science, left and right parties have different electoral constituencies. Representing wage earners, left parties politically advance the interests of the working class. As workers derive their income from salaried employment and face a number of labor market risks related to health, old age, unemployment, etc., they have a preference for strong social protection. Accordingly, the prediction is that left-leaning governments are associated with more extensive labor market regulation and welfare protection than right-leaning governments. By extension, this reasoning also leads us to believe that left-wing governments should be more responsive than their right-wing counterparts to worker concerns about economic insecurities emanating from the international economy and to demands for a fair "level playing field" and, thus, more inclined to include LPs in PTAs.

This prediction is consistent with the assumption that the support of political parties for social clauses is closely associated with their ideological orientation. In line with their preference for state intervention in the economy, left-leaning governments should be particularly inclined to introduce social regulatory standards in trade agreements. It also dovetails with one strand of the literature on the political economy of trade policy which emphasizes the role of political parties and partisan influences. Milner and Judkins (2004), for instance, argue that partisanship does matter with right parties consistently taking more free trade stances and left parties advocating for more protectionist policies.

In recent decades, it has been commonplace in the political economy literature to argue that the political space for partisan differences over economic policies has disappeared. In view of the consequences of an increasingly open and interdependent economy, some predicted the decline of social democracy and the cross-national convergence of socioeconomic policies along neoliberal lines affecting left-wing parties more than right-wing parties (e.g., Mishra 1999). Although a second wave of globalization literature has questioned the predictions of the neoliberal convergence theory stressing conflicting arguments about the extent to which globalization affects socio-economic policies and political parties' ideological shifts (e.g., Adams et al. 2009), partisan differences appear to have narrowed in recent years (Milner and Judkins 2004).

Yet it is plausible to argue that this development is at best incomplete and too recent to fully wash away partisan effects. For that to happen one would expect the business community - the core constituency of right-leaning parties - as well to lessen opposition to trade-labor linkage. However, the Employers Group's challenge to the right to strike during the International Labour Conference in 2012 provides little hope for that to happen. As Novitz 2012: 21) points out, maybe "what the Employers' group is actually seeking is a new political deal reflecting their enhanced power as a lobby group", grasping on a moment ideal for them to "push an agenda of deregulating international labour law" (La Hovary 2013: 365). We have, hence, the basis for our second hypothesis:

- Hypothesis 2 (Left government): When a left-wing party controls government in at least one of the member states of a PTA, it is associated with far-reaching labor provisions in that PTA.

The two variables introduced so far may interact in shaping the design of PTAs. According to the power resources approach, the ability of left governments to deliver 
progressive social legislation crucially depends on trade union strength and their ability to mobilize workers politically (e.g., Korpi 1983; Huber and Stephens 2001). The political links between left-wing parties and trade unions have historically been strong. Trade unions campaigned for left-leaning parties by mobilizing voters, and unionized workers massively voted for these parties. In return, left governments established corporatist institutions and other union-friendly labor market institutions that promoted the interests of workers. In historical-comparative perspective, the extent to which left governments provide social protection depends on the relative power and political resources of organized labor (Korpi 1983; Esping-Andersen 1990).

When it comes to the extent of LPs in PTAs, we argue that it is when left governments are backed or pressured by strong labor unions that the parties to a trade agreement are the most likely to commit to comprehensive LPs. This is, on the one hand, because strong labor unions with high density rates can assert the necessary pressure and visibility needed for such provisions to be high on the agenda and can play an important role in shaping public opinion towards trade policies. On the other hand, as argued above, it is the left governments' propensity to provide greater protection for workers that will make them more perceptive to concerns about the inclusion of LPs in PTAs compared to right-leaning governments. To illustrate, the US labor movement opposed NAFTA and it is only after Bill Clinton defeated George Bush Sr. that labor unions gained enough influence to extract a concession in the form of a side agreement on labor (Manger 2009: 86). In short, the influence of trade unions and of left governments might reinforce each other. Hence our third hypothesis:

- Hypothesis 3 (Labor power and left government reinforcing each other): When trade unions are strong and left-wing parties control the government in at least one member country of a PTA, it is associated with far-reaching labor provisions in that PTA.

The effect of trade union strength might also be moderated by regime type (Caraway et al. 2012). The influence of labor unions on policy ought to be stronger where governments are electorally accountable. Democratic regimes are characterized by electoral accountability. Incumbent politicians stand for re-election at regular intervals and they must gain the support of voters to stay in office. Because workers form a large swath of the electorate, governments in modern democracies are likely to be responsive to the grievances and demands of workers and of their representatives. By contrast, autocratic regimes lack political accountability. Autocrats are far less constrained by electoral concerns either because elections simply do not exist or because they are rigged. Leaders in autocracies are therefore less inclined to seek the support of, and be responsive to, civil society groups, including labor unions, as their political survival does not depend on it. This reasoning forms the basis of our fourth hypothesis.

- Hypothesis 4 (Labor power conditional on regime type): Stronger trade unions in at least one member country if that country is democratic are associated with farreaching labor provisions in that PTA.

Finally, there might be heterogeneity among workers as to the desirability of the inclusion of LPs in PTAs. We expect a cleavage pitting unskilled workers who tend to 
be supportive of labor clauses against skilled workers who tend to oppose them. According to the conventional trade theory model, in developed countries unskilled workers should support and skilled workers should oppose LPs, whereas in developing countries we would expect just the opposite. However, the new new trade theory (Melitz 2003) predicts trade openness to favor skilled over unskilled labor, independent of a country's level of development. This model starts with the empirical observation that few firms are able to engage in exporting activities (Bernard et al. 2007). Exporters tend to be more productive than non-exporters, enabling them to pay the high costs associated with entering and competing in foreign markets. Exporting firms also tend to be technological leaders as trade openness is thought to induce a quality upgrading of firms (Goldberg and Pavcnik 2007: 66). Empirical evidence from developed and developing countries suggests that exporting firms are indeed relatively more skillintensive than non-exporting firms (Bernard and Jensen 1997; Hanson and Harrison 1999). Trade thus leads to an increased demand for skilled workers in both developed and developing countries.

The implication is that we should expect the same cleavage over LPs in PTAs in developing and in developed countries. Skilled workers in the export-oriented industries oppose (comprehensive) LPs in PTAs. The export-oriented firms in which they are employed tend to be involved in global supply chains and, thus, are dependent on cheap imported intermediate inputs. They also fear that labor issues might end up being a deal-breaker in trade negotiations and, as a result, prefer that such issues should not be regulated through trade agreements. Skilled workers in developing countries, moreover, are concerned that stringent labor standards might lead to a deterioration of comparative advantage and that enforceable labor standards might result in the withdrawal of preferential market access.

Unskilled workers are mainly employed in import-competing sectors. For them, labor standards serve as barriers to trade. From their perspective, sustainability standards in PTAs help establish a level playing field by ensuring that firms in the partner countries play by the rules, that is, for instance, that they do not encourage trade by lowering existing levels of labor protection. Lechner (2016) has made a similar argument about the preferences of import-competing versus export-dependent industries with respect to NTIs in PTAs. In line with our expectation, Burgoon (2009) finds that highly educated and high-income individuals are less likely to support EU fair trade protection (i.e., less likely to oppose imports from countries where working conditions are unacceptable). Hence our final hypothesis:

- Hypothesis 5 (Relative power of skilled labor): A higher ratio of skilled workers to unskilled workers in at least one member country of a PTA is negatively associated with far-reaching labor provisions in that PTA.

\section{Data}

Central to our analysis are the PTAs themselves. Our source for the PTAs is the DESTA database (Dür et al. 2014). DESTA is a recent dataset on the content of PTAs that comprises approximately 790 PTAs signed in the post-World War II period, providing a larger dataset than the one maintained by the WTO. We focus on the period 1990-2016 
for a total of 483 PTAs. The lower temporal boundary is determined by the fact that LPs in PTAs emerged in the early 1990s - NAFTA being the first PTA with comprehensive LPs.

To code the PTAs in terms of the content of LPs, we developed a coding table consisting of 140 items referring to the protection of labor rights and conditions of work (Raess and Sari 2017). ${ }^{2}$ The template is structured around six overarching categories: I. Preambular LPs; II. Substantive commitments; III. Obligations; VI. Enforcement; V. Cooperation; and VI. Institutions. Each category has a detailed list of items against which the PTAs are coded with a binary coding.

Under preambular LPs we code aspirational statements in the preamble and objectives parts of the agreements. Under substantive commitments we list items related to fundamental rights at work, conditions of work, relevant international instruments and also domestic law related commitments such as non-derogation, effective enforcement, and access to domestic courts. Under obligations, following a strict legal interpretation of the agreement texts, we code the extent of obligations undertaken by the signatory parties. Under enforcement we apply the distinction adopted by a WTO mapping (Chase et al. 2016) and distinguish between three types of dispute settlement mechanisms (Political, Quasi-Judicial and Judicial) and also code provisions with regard to remedies provided in relation to LPs. Our cooperation category captures a list of issues that can be covered by such commitments. The sixth and last category depicts the attributes that can determine the role the institutional set-up may have in the effective implementation of LPs. Such items include the coding of the type of bodies responsible for the cooperation, their operation, the status of participants, the involvement of third parties, and also the means by which the cooperation activities are carried out.

\subsection{Dependent variables}

Based on these data, we generate two different variables. For one, we produce the ordinal variable LP protect that ranges from 0 (no LPs) to 5 (most protecting LPs). The values that this variable takes on are defined as follows: $0=$ agreements with no LPs whatsoever; $1=$ agreements with an exclusive reference to "create employment opportunities" in the preamble and/or objectives; 2 =agreements with references to "improve working conditions" and/or other labor rights in the preamble and/or objectives (with or without reference to "create employment opportunities"); 3 =agreements with substantive or cooperation-related LPs, without deep institutional framework or strong enforcement mechanism; $4=$ agreements with substantive or cooperation-related LPs with deep institutional framework but without strong enforcement; $5=$ agreements with substantive or cooperation-related LPs with strong enforcement mechanism. ${ }^{3}$

The rationale for this ordering is that, although still subject of academic debate (Hulme 2016), LPs in preambles are predominantly considered to differ

\footnotetext{
${ }^{2}$ We coded separately references to "create employment opportunities" mostly found in the preamble of PTAs because, unlike all other items in our template, such references do not pertain to the family of provisions aiming at promoting and protecting labor rights. We use this provision in our empirical analysis (see below). ${ }^{3}$ Initially we included a separate score for PTAs with references exclusively under Obligations (together with the underlining reference to substantive commitment(s)). Given that there is no such PTA in our sample, we decided not to include this category into our final measure.
} 
in terms of their legal effect from those found in other parts of the agreement in that they do not establish specific rights and obligations (and as such cannot directly be subject of dispute settlement) but hold an interpretive role (see also Bourgeois et al. 2007: 13). We thus consider agreements where the protection of labor rights and conditions at work are set as a priority in the main body of the treaty text as containing more comprehensive LPs. Deep institutional framework refers to cases where a separate body is established for the monitoring and implementation of LPs in PTAs together with the possible participation of third parties (such as social partners, ILO, NGOs, or others) therein. Strong enforcement refers to cases where LPs can be subject of quasi-judicial or judicial dispute settlement mechanism with the possible imposition of unilateral sanctions (such as trade sanctions, monetary compensation, or other appropriate measures). ${ }^{4}$ The resulting variable has a large number of zeros, as most PTAs in our dataset do not include any LPs (see Fig. 1). Below, to analyze these data, we use an ordered logistic model. The results are robust to using an ordered probit model instead.

We check the robustness of our results using a simple dichotomous variable on whether a PTA includes any provisions on labor standards (LP protect dichotomous). No fewer than 256 agreements $(53 \%)$ include no reference to labor standards whatsoever. Using this dichotomous variable as robustness check allows us to see whether our argument not only explains the depth of labor commitments, but also the simple decision on whether to mention the issue in the first place.

\subsection{Predictors}

We measure labor power relying on trade union density, the most basic and commonly used indicator of the strength of organized labor. It is defined as net union membership as a proportion of wage and salary earners in employment. ${ }^{5}$ To increase country coverage, we combined the following data sources: the ICTWSS database (Visser 2015); from a joint project between Jelle Visser and the ILO to collect trade union density and collective bargaining coverage data in developing countries; the ILO's 2016 IR Indicators: TU Membership Statistics; the ILO's 2011 Social Dialogue Indicators; and the OECD. Despite our best efforts, the data remains spotty. For countries for which we had at least one data point, we therefore replaced missing observations with the mean across the non-missing observations. We chose this approach because the data are relatively time-invariant over the short time period considered in this paper. For this and all other variables introduced below, we calculated values for the EU and European Free Trade Association by using the mean (or the median for dichotomous variables) across all member countries. To arrive at a value for this variable at the PTA level, we use the maximum value across all PTA members (Union density). By taking the maximum, we assume that the

\footnotetext{
${ }^{4}$ Provisions with teeth are logically further up our scale than provisions without teeth; see also Abbott et al. (2000) continuum from soft to hard law.

${ }^{5}$ Net union membership is total union membership minus union members outside the active, dependent and employed labor force (i.e., retired workers, independent workers, students, unemployed).
} 


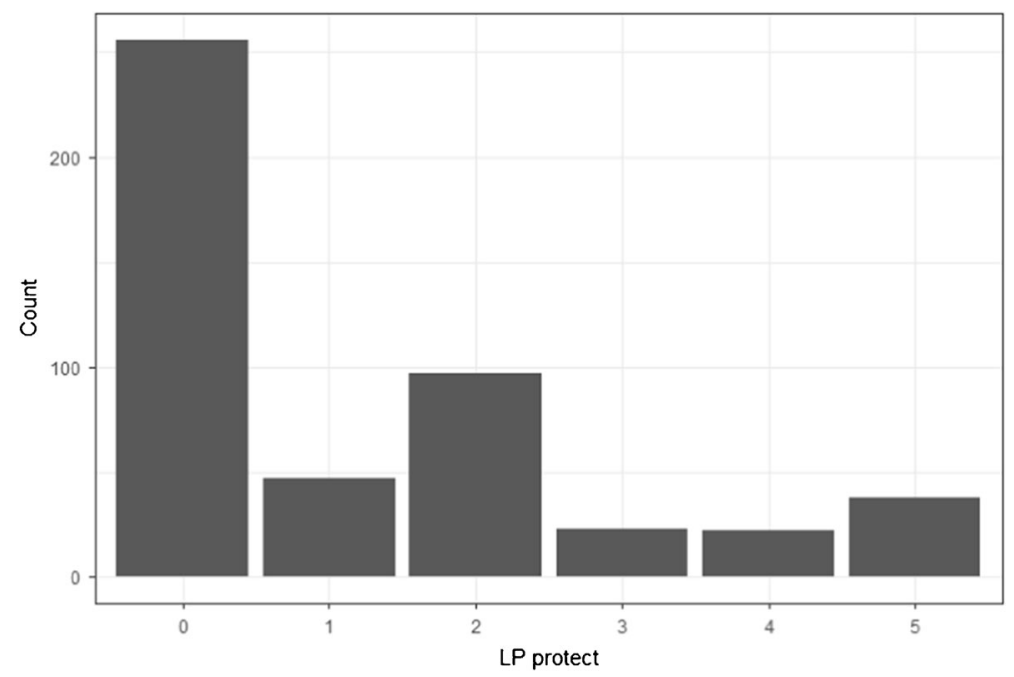

Fig. 1 Distribution of LP protect. Note: data for 483 PTAs signed by 199 different countries

countries that are most interested in having LPs included in PTAs (because labor power is high) get their way. ${ }^{6}$ Because the negotiations leading up to the conclusion of a PTA tend to last for more than one year, we use the average value across three years (year of signature, $t$ minus 1 and $t$ minus 2 , omitting missing values) for this variable and also for the other variables below that are time variant. We calculate the interaction terms needed to test Hypotheses 3 and 4 at the country level and then take the maximum across these values as measure for the PTA.

Our measure of government partisanship comes from the World Bank's Database of Political Institutions (Keefer 2012). We use the variable "EXECRLC" which measures the party orientation with respect to economic policy. Left government takes the value of 1 when the party orientation is left and 0 when it is right or center. Left parties are defined as communist, socialist, social democratic or left wing. ${ }^{7}$ We recoded the communist governments of China, Cuba, Laos, and Vietnam as non-left governments because these are one-party systems that fully control the union structure and are thus, paradoxically, inimical to Western-style labor rights. At the level of the PTA, this variable is coded 1 if at least one signing party has a left government (Left government).

\footnotetext{
${ }^{6}$ One might object that small countries have little bargaining power over large countries, and if LPs are not highly regarded by the large country, they may well be excluded from the PTA. One solution would be to take the weighted average of union density across members of the PTA, where weights are either GDP or the value of trade. We do not implement this solution for three reasons. First, there are good reasons to be sceptical of GDP (or absolute levels of trade) as a measure of bargaining power in trade negotiations. Bargaining power is a function of the relative desire that countries have for an agreement, which is affected by trade flows, the availability of alternative markets, the existence of supply chains, etc. GDP thus is at most a very rough proxy. Second, even if GDP (trade) did capture bargaining power well, it is not clear how well overall bargaining power explains bargaining power on a specific issue within the negotiations, such as LPs. This is so because countries differ in their attribution of salience to different topics. Finally, we include dummy variables for the US, the EU and North-South agreements in the models to capture overall power relations.

${ }^{7}$ The World Bank's DPI has missing values for Switzerland. We decided to code Switzerland as being governed by right-wing governments over the entire period under consideration.
} 
We use Polity scores to capture the level of democracy of countries (Marshall et al. 2016). We rescale them so that they range from 0 to 1 , as this facilitates using this variable in the interaction term introduced below. Again, we use the maximum across all member countries as the value for the PTA (Democracy).

Finally, we use potential labor power $(P L P)$ as our measure of the relative strength of skilled workers to unskilled workers. This measure was introduced by Rudra (2002) and is calculated as follows ${ }^{8}$ :

PLP $=\frac{\text { Number } \text { of skiller workers }}{\text { Number of low-skilled workers }} \frac{*}{\text { Surplus laboras\%working-agepopulation }}$

Our use of this specific measure is based on the assumption that an increase in surplus labor weakens the influence of skilled workers. Just as low-skilled workers, surplus labor should support LPs in PTAs. Below we show that our results are robust to omitting surplus labor from this formula. Since Rudra's dataset goes from 1972 to 1995, it does not cover much of the period we are interested in. Due to changes in industry classification that occurred in the intervening period, moreover, it was not possible to update her dataset. As a result we calculated new high skilled to low skilled ratios using employment data from UNIDO for the period 1990-2012. ${ }^{9}$ We could rely on surplus labor data up to 2012 calculated by Rudra. ${ }^{10}$ Again, we faced the problem of a large number of missing observations, so we calculated country means and used those to replace missing observations before calculating the PLP measure. As before, we used the maximum across all member countries as value for the PTA $(P L P)$.

\subsection{Control variables}

In the multivariate models, we include several control variables. First, we control for the overall level of ambition of a PTA. Some PTAs are more far-reaching than others. The more far-reaching a PTA is, the more LPs it should also include. We use the depth index provided by the DESTA project as measure of the ambitiousness of a PTA (Dür et al. 2014). This measure ranges from 0 to 7 , with higher values indicating deeper agreements (Trade depth). Second, we control for the diffusion of LPs in PTAs over time. We do so by including the mean value on $L P$ protect across all PTAs in the year prior to the signature of a PTA in our models (Diffusion). The value of this variable increases over time, but not monotonously. In the model with LP protect dichotomous we calculate this variable for the dichotomous version of the dependent variable (Diffusion dichotomous).

As the European Union and the United States are powerful players in terms of shaping the design of PTAs (Baccini et al. 2015), we include dummies that are coded

\footnotetext{
${ }^{8}$ Whereas for Rudra PLP is an indicator of labor power, for us it is, as per the equation, a measure of the relative power of skilled to unskilled labor.

${ }^{9}$ In the ISIC Rev. 3 industry classification, the low-skill industry codes are as follows: 17 Textiles; 18 Wearing apparel, fur; 19 Leather, leather products and footwear; 20 Wood products (excl. furniture); 21 Paper and paper products; 25 Rubber and plastics products; 26 Non-metallic mineral products; 27 Basic metals; 28 Fabricated metal products; 36 Furniture. High-skill categories are: 24 Chemicals and chemical products; 29 Machinery and equipment; 30 Office, accounting and computing machinery; 31 Electrical machinery and apparatus; 32 Radio, television and communication equipment; 33 Medical, precision and optical instruments; 34 Motor vehicles, trailers, semi-trailers; 35 Other transport equipment.

${ }^{10} \mathrm{We}$ are grateful to her for sharing these data.
} 
1 for PTAs that involve at least one of these two entities (EU, US). We also control for the level of development of the countries signing a PTA by including two dummies, one for North-North agreements and one for South-South agreements (North-North and South-South). The coefficients for these two dummies need to be interpreted relative to the base category, namely North-South agreements. Finally, we include two time period dummies (Period 1999-2007 and Period 2008-2016) to control for time trends. The reason for the cutoff points for these time dummies is that the ILO Declaration of Fundamental Principles and Rights at Work, which is often referred to in PTA labor chapters, was signed in 1998. We divide the remaining years into two periods of equal length. ${ }^{11}$ Table $\mathrm{A} 1$ in the Online Appendix provides summary statistics for all the variables.

\section{Empirical analysis}

We start the empirical analysis with a model with $L P$ protect as dependent variable that includes the various predictors and control variables introduced above, but no interaction terms (Model 1 in Table 1). As expected in Hypothesis 1, the coefficient for Union density is positive and statistically significant. PTAs signed by countries with high union density are associated with more comprehensive LPs than other PTAs. The substantive effect of this variable is large: when it takes its minimum value (2), the expected probability of an agreement including no LPs at all is 0.68 . This probability drops to 0.19 when Union density takes on its maximum value (97). In line with Hypothesis 2, the coefficient for Left government is positive. However, the coefficient is not statistically significant, which reflects the small magnitude of the effect that we estimate for this variable (the probability of having no LPs in a PTA drops from 0.51 to 0.48 when moving from 0 to 1 on the Left government variable). We thus do not find support for Hypothesis 2 . The statistically significant controls in this model are Trade depth, EU, US, South-South, and Period 1999-2007.

In Model 2, we include an interaction term between Left government and Union density to test Hypothesis 3. The coefficient for Union density remains similar to the one presented in Model 1. In the presence of the interaction term, this means that when a non-left party controls the government, PTAs signed by countries with high union density include more LPs than PTAs signed by countries with low labor power. The coefficient for Left government now is negative but remains statistically insignificant. Importantly, the coefficient for the interaction term is positive and statistically significant at the $95 \%$ level. This indicates that left government and trade union strength do indeed reinforce each other, as expected in Hypothesis 3.

In Fig. 2, we show this interaction graphically. In the left panel, we show the predicted probability that LP protect takes the value of 0 (the minimum) for left and non-left governments as a function of Union density. As expected, this probability decreases strongly for left governments as the power of trade unions increases. While the difference to non-left governments does not become statistically significant at the 95\% level, the decline is sharper for left governments than for non-left governments. In the panel to the right, we show the same probability for $L P$ protect taking the value of 5 .

\footnotetext{
$\overline{11}$ The results are robust to using dummies for 5-year periods instead.
} 
Table 1 Main results

Dependent variable:

LP protect

(1)

(2)

(3)

\begin{tabular}{|c|c|c|c|}
\hline \multirow[t]{2}{*}{ Union density } & $0.024 * * *$ & $0.015 * *$ & 0.010 \\
\hline & $(0.006)$ & $(0.007)$ & $(0.010)$ \\
\hline \multirow[t]{2}{*}{ Left government } & 0.119 & -0.543 & 0.073 \\
\hline & $(0.226)$ & $(0.338)$ & $(0.229)$ \\
\hline \multirow[t]{2}{*}{ PLP } & $-0.307 * * *$ & $-0.319 * * *$ & $-0.308^{* * * *}$ \\
\hline & $(0.083)$ & $(0.085)$ & $(0.084)$ \\
\hline \multirow[t]{2}{*}{ Democracy } & 1.030 & 1.149 & 0.017 \\
\hline & $(1.031)$ & $(1.115)$ & $(1.132)$ \\
\hline \multirow[t]{2}{*}{ Trade depth } & $0.585^{* * * *}$ & $0.574 * * *$ & $0.595 * * *$ \\
\hline & $(0.078)$ & $(0.078)$ & $(0.078)$ \\
\hline \multirow[t]{2}{*}{ Diffusion } & 0.102 & 0.076 & 0.046 \\
\hline & $(0.237)$ & $(0.240)$ & $(0.241)$ \\
\hline \multirow[t]{2}{*}{ EU } & $0.653^{*}$ & $0.642 *$ & 0.598 \\
\hline & $(0.379)$ & $(0.380)$ & $(0.381)$ \\
\hline \multirow[t]{2}{*}{ US } & $4.050 * * *$ & $4.079 * * *$ & $4.223 * * *$ \\
\hline & $(1.130)$ & $(1.132)$ & $(1.134)$ \\
\hline \multirow[t]{2}{*}{ North-North } & -0.770 & -0.766 & -0.835 \\
\hline & $(0.613)$ & $(0.620)$ & $(0.627)$ \\
\hline \multirow[t]{2}{*}{ South-South } & $-1.317 * * *$ & $-1.245^{* * *}$ & $-1.166^{* * * *}$ \\
\hline & $(0.319)$ & $(0.322)$ & $(0.327)$ \\
\hline \multirow[t]{2}{*}{ Period 1999-2007 } & $-0.567 * *$ & $-0.521 * *$ & -0.386 \\
\hline & $(0.257)$ & $(0.264)$ & $(0.271)$ \\
\hline \multirow[t]{2}{*}{ Period 2008-2016 } & 0.078 & 0.348 & 0.397 \\
\hline & $(0.361)$ & $(0.379)$ & $(0.391)$ \\
\hline \multirow[t]{2}{*}{ Union density*Left gov. } & & $0.022 * *$ & \\
\hline & & $(0.009)$ & \\
\hline \multirow[t]{2}{*}{ Union density*Democracy } & & & $0.027 * *$ \\
\hline & & & $(0.012)$ \\
\hline Observations & 405 & 396 & 405 \\
\hline Log Likelihood & -446.18 & -438.29 & -443.68 \\
\hline
\end{tabular}

Results from ordinal logistic regression models. The models also included intercepts, but they are omitted from this table

${ }^{*} p<0.1 ;{ }^{* *} p<0.05 ;{ }^{* * *} p<0.01$

As expected, Union density is associated with a sharp increase in this probability for left governments, but less so for non-left governments.

In Model 3 we interact Union density with Democracy to test Hypothesis 4. The coefficient for Union density remains positive but it is no longer statistically significant. This means that in the presence of autocratic regimes, PTAs are not more likely to include 

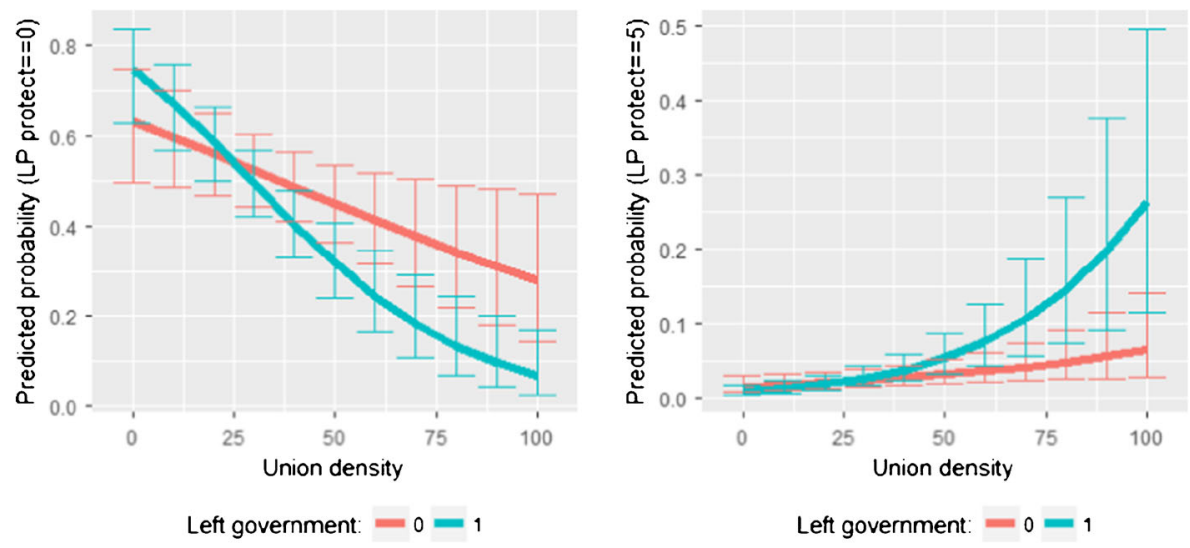

Fig. 2 Interaction Left government times Union density. Note: the figure shows predicted probabilities of the dependent variable taking the values of 0 (left-hand side) and 5 (right-hand side). These probabilities are calculated while keeping all other variables at their means. The error bars indicate the $90 \%$ confidence intervals

far-reaching LPs when trade unions are strong than when they are not. The coefficient for the interaction term is positive and statistically significant at the $95 \%$ level. As interpreting this coefficient from the results in Table 1 alone is difficult, we show the effect graphically (see Fig. 3). In line with our expectation, for regimes with a low score on Democracy (in this case, we used the value of 0.15 , which is equivalent to a Polity 2 score of -7 ) the probability that $L P$ protect takes on the value of 0 does not depend on Union density (left-hand side). ${ }^{12}$ For a full democracy (Polity 2 score of 10), the probability of LP protect taking on the value of 0 strongly declines as Union density goes up. By contrast, the probability of labor rights being protected strongly in a PTA (LP protect taking the value of 5) increases much more strongly for democracies than for non-democracies as union density increases (right-hand side of Fig. 3). This evidence provides support for Hypothesis 4.

Finally, the coefficient for PLP is negative and statistically significant in all three models presented in Table 1. In other words, PTAs signed by countries with a high skilled to unskilled labor ratio are less likely to protect labor rights comprehensively than PTAs concluded by countries where the relative power of skilled to unskilled workers is low. This finding is in line with Hypothesis 5. Again, the substantive effect of this variable is sizeable: when moving from its minimum (0) to its maximum (7.7), the probability of an agreement not including any LPs increases from 0.31 to 0.83 .

\section{Robustness checks}

We ran several checks to see how robust our results are to specific decisions made in terms of operationalization. For one, we re-ran our results with LP protect dichotomous as dependent variable (see Table A2 in the Online Appendix). The results corroborate all our substantive findings. The conditional effects now are even stronger than in the baseline models. Figure 4, for example, shows the sharp increase in the probability of a

\footnotetext{
12 The confidence intervals for this estimation are very large, as we have few observations in the dataset for any specific value on Democracy that is smaller than 1. A dichotomous version of Democracy would resolve this issue, but leads to considerable loss of information.
} 

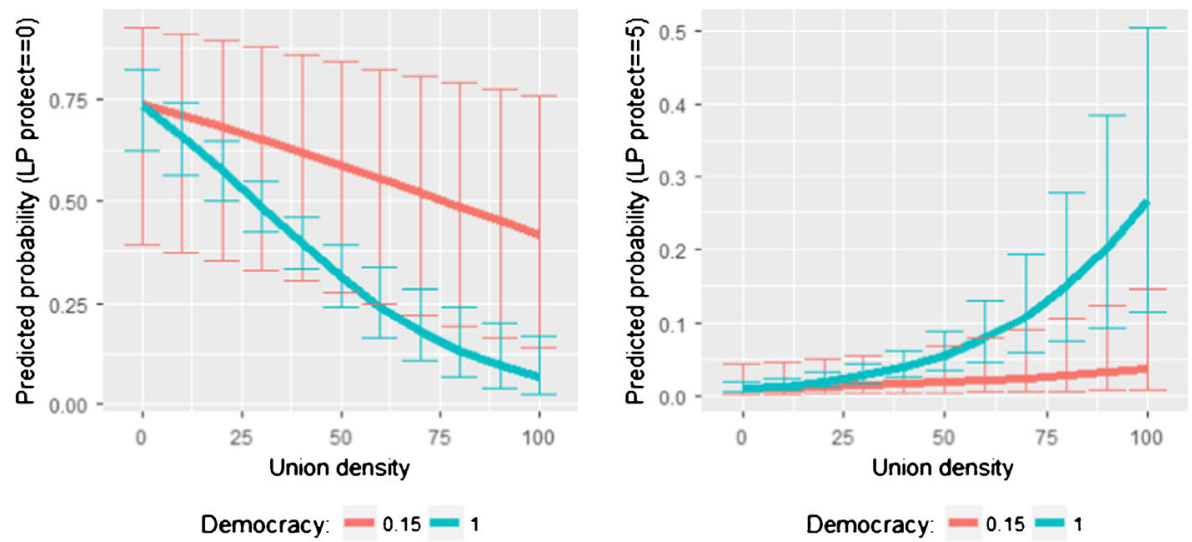

Fig. 3 Interaction Democracy times Union density. Note: see Fig. 2

PTA including LPs as union density increases, if at least one member country is highly democratic. This probability increases from 0.32 (when Union density equals 0) to 0.96 (when Union density equals 100). As before, the standard errors for the autocratic governments are very large. This is so because this is an interaction between two continuous variables, and there are very few countries in the dataset with any specific value on Democracy lower than 1.

Second, to see whether our results for the strength of skilled labor are sensitive to the inclusion of labor surplus in the calculation of PLP, we re-ran the analysis substituting the high- to low-skill ratio (without labor surplus) for PLP. The results are closely in line with what we get for PLP (see Table A3 in the Online Appendix). The coefficient for the high- to low-skill ratio is negative and statistically significant in all three models, as expected in Hypothesis 5.

Third, as we lose a considerable number of observations because of missing values on our predictors, ${ }^{13}$ we re-ran the models relying on multiple imputation. ${ }^{14}$ These models again confirm the findings presented above (see Table A4 in the Online Appendix). Fourth, we also ran the models with the predictors taking the value of the year of signature, rather than averaging values across three years. The results are again highly robust (Table A5 in the Online Appendix). Overall, therefore, the results presented before are highly robust to changes in operationalization and multiple imputation.

Finally, is there a concern that PTAs may not be formed if LPs are either too stringent or not stringent enough, thereby introducing sample selection bias? We suggest that the answer is "no", using Latin American experiences as an illustration. Although Latin American countries have historically adopted a defensive stance when it comes to the trade-labor linkage, viewing protectionist intentions behind such a link, many of them have signed PTAs with the US including strongly enforceable LPs (Chile

\footnotetext{
13 This is particularly true for our government partisanship variable. When we drop this variable from the analysis, the number of missing observations drops from 78 to 47 . However, all substantive results discussed before remain the same even without this variable.

${ }^{14}$ We used the R package amelia for these models (Honaker et al. 2015). Concretely, we drew five datasets from the original dataset. In each, the missing observations were estimated based on the mean and standard deviation of each variable, while taking into account time trends. We ran the models on each of the five imputed datasets, before combining the coefficients and standard errors.
} 

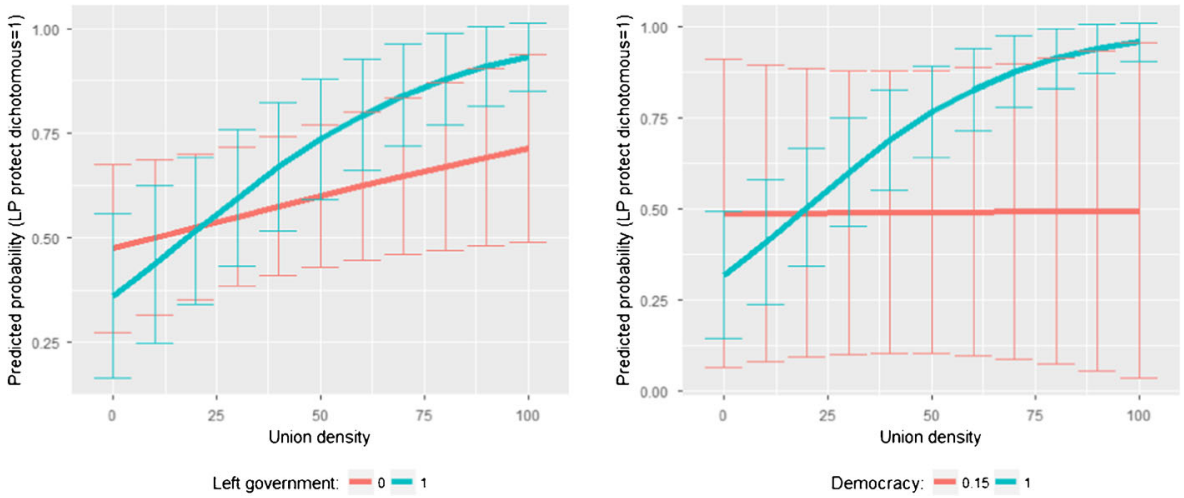

Fig. 4 Interactions Union density times Left government and Union density times Democracy (robustness analysis)

in 2003, the Central American countries in 2004, Peru in 2006, Colombia in 2006, and Panama in 2007). In the case of Chile and Peru, it has been argued that the adoption of obligations in the labor (and environment) area(s) was the (domestically acceptable) price to pay to obtain guaranteed preferential access to the large US market (Motta Veiga and Rios 2008) - an argument that likely carries over to the smaller Latin American countries. By contrast, large countries such as Argentina and Brazil have not concluded any major PTA with developed countries since the creation of Mercosur, in spite of several attempts being made (e.g., FTAA and EU-Mercosur during the 2000s). As far as Brazil is concerned, resistance to negotiate PTAs had to do with opposition to rules and discipline in areas such as investment protection, intellectual property, government procurement and trade in services, provisions seen as curtailing the conduct of an autonomous industrial policy (Motta Veiga and Rios 2009), rather than with objections related to the introduction of LPs.

\section{Conclusion}

To our knowledge, this is the first paper that systematically and directly investigates the effect of trade unions, government partisanship and skilled labor on the inclusion of LPs in PTAs. We expected trade union power and left governments to be positively associated with more far-reaching LPs in PTAs. We also expected the effect of trade unions to be reinforced by the presence of left governments, on the one hand, and to be conditional on regime type, on the other. Finally, we argued that a greater skilled to unskilled labor ratio should be negatively associated with the depth of LPs. Using the novel LABPTA dataset that covers 483 PTAs signed between 1990 and 2016, our quantitative analysis finds strong support for these expectations, especially those concerning the role of trade unions and a country's skill profile.

Specifically, we find that stronger trade unions are associated with more far-reaching LPs in PTAs, whereas a higher skilled to unskilled labor ratio is associated with less stringent LPs. We do not find a direct association between left governments and the depth of LPs in PTAs. However, we find that trade union power and left governments 
reinforce each other in terms of deepening labor protection provisions in PTAs. Trade union strength also matters more for the design of LPs in PTAs in democracies. In other words, the strength of trade unions matters more if they try to influence a democratic government than if they need to convince a non-democratic government. Overall, these findings offer strong support for our argument about the impact of domestic factors on the design of LPs in PTAs.

Some scholars have suggested that fundamental labor rights have developed considerable normative power (Drezner 2001; Van den Putte and Orbie 2015). They claim that LPs in trade agreements, particularly in the EU context, achieved the status of an "unobjectionable norm" and hence have become more of an issue of human rights championing. Our results suggest otherwise. Indeed, unless a class-struggle labor movement actively champions the trade-labor linkage, LPs are unlikely to feature (prominently) in PTAs. Looking ahead, the dwindling support for labor unions around the world does not bode well for the inclusion of more far-reaching and highly enforceable LPs in PTAs. Neither does up-skilling related to technological change and globalization.

Acknowledgments This paper is part of the Swiss Network for International Studies funded project "A Social Clause through the Back Door: Labor Provisions in Preferential Trade Agreements" (Call for projects 2014; project coordinator: Dr. Damian Raess). We thank Joost Pauwelyn and Sonja Peters for helpful discussions and the latter for assistance with the coding of labor provisions. We also thank participants in the 2016 ECPR General Conference, the 2017 ISA Annual Convention, and the project's closing workshop, especially Asif Efrat, Martin Myant, Claire Peacock and Thomas Sattler, for helpful comments on an earlier draft. Finally, we thank two anonymous reviewers, the Editors of the special issue, and the Editor for helpful comments and guidance.

Open Access This article is distributed under the terms of the Creative Commons Attribution 4.0 International License (http://creativecommons.org/licenses/by/4.0/), which permits unrestricted use, distribution, and reproduction in any medium, provided you give appropriate credit to the original author(s) and the source, provide a link to the Creative Commons license, and indicate if changes were made.

\section{References}

Abbott, K. W., Keohane, R. O., Moravcsik, A., Slaughter, A.-M., \& Snidal, D. (2000). The concept of legalization. International Organization, 54(3), 401-419.

Adams, J., Haupt, A., \& Stoll, H. (2009). What moves parties? The role of public opinion and global economic conditions in Western Europe. Comparative Political Studies, 42(5), 611-639.

Adriaensen, J., \& González-Garibay, M. (2013). The illusion of choice: The European Union and the tradelabor linkage. Journal of Contemporary European Research, 9(4), 542-559.

Anner, M. (2011). Solidarity transformed: Labor responses to globalization and crisis in Latin America. Ithaca: Cornell University Press.

Baccini, L., Dür, A., \& Haftel, Y. Z. (2015). Imitation and innovation in international governance: The diffusion of trade agreement design. In Trade Cooperation: The Purpose, Design and Effects of Preferential Trade Agreements, eds. Andreas Dür and Manfred Elsig. Cambridge: Cambridge University Press.

Baghdadi, L., Martinez-Zarzoso, I., \& Zitouna, H. (2013). Are RTA agreements with environmental provisions reducing emissions? Journal of International Economics, 90, 378-390.

Bernard, A. B., \& Jensen, J. B. (1997). Exporters, skill upgrading, and the wage gap. Journal of International Economics, 42(1-2), 3-31.

Bernard, A. B., Jensen, J. B., Redding, S. J., \& Schott, P. K. (2007). Firms in international trade. Journal of Economic Perspective, 21(3), 105-130. 
Bhagwati, J. (1995). Trade liberalisation and "fair trade" demands: Addressing the environmental and labour standards issues. The World Economy, 18(6), 745-759.

Bourgeois J., Dawar, K., \& Evenett, S.J. (2007). A comparative analysis of selected provisions in free trade agreements. Commissioned by DG Trade. Available at: http://www.kamaladawar. com/userfiles/file/downloads/A\%20Comparative\%20Analysis $\% 20$ of\%20Selected\%20FTAs.pdf. Accessed 6 Nov 2017.

Burgoon, B. (2009). The distinct politics of the European Union's 'fair trade' linkage to labour standards. European Foreign Affairs Review, 14, 643-661.

Burgoon, B. \& Hiscox, M. (2000). Trade openness and political compensation: Labor demands for adjustment assistance. Paper presented at the Annual Meeting of the American Political Science Association.

Cameron, D. (1978). The Expansion of the Public Economy: A Comparative Analysis. American Political Science Review, 72(4), 1243-1261.

Caraway, T., Rickard, S., \& Anner, M. (2012). International negotiations and domestic politics: The case of IMF labor market conditionality. International Organization, 66(1), 27-61.

Chase, C., Yanovich, A., Crawford, J.-A., \& Ugaz, P. (2016). Mapping of disputes settlement mechanisms in regional trade agreements - innovative or variations on a theme? In R. Acharya (Ed.) Regional Trade Agreements and the Multilateral Trading System. Cambridge: Cambridge University Press.

Drezner, D. W. (2001). Globalization and policy convergence. International Studies Review, 3(1), 51-78.

Dür, A., \& Elsig, M. (Eds.). (2015). Trade cooperation: The purpose, design and effects of preferential trade agreements. Cambridge: Cambridge University Press.

Dür, A., Baccini, L., \& Elsig, M. (2014). The Design of International Trade Agreements: Introducing a new dataset. Review of International Organizations, 9(3), 353-375.

Elliott, K. A., \& Freeman, R. B. (2003). Can Labor Standards Improve Under Globalization? Washington, D.C.: Peterson Institute for International Economics.

Esping-Andersen, G. (1990). The three worlds of welfare capitalism. Oxford: Polity.

Giumelli, F., \& van Roozendaal, G. (2017). Trade agreements and labour standards' clauses: Explaining labour standards developments through a qualitative comparative analysis of US free trade agreements. Global Social Policy, 17(1), 38-61.

Goldberg, P. K., \& Pavcnik, N. (2007). Distributional effects of globalization in developing countries. Journal of Economic Literature, 45(1), 39-82.

Hafner-Burton, E. (2005). Trading human rights: How preferential trade agreements influence government repression. International Organization, 59, 593-629.

Hafner-Burton, E. (2009). Forced to be good. Why trade agreements boost human rights. Ithaca: Cornell University Press.

Hanson, G. H., \& Harrison, A. E. (1999). Trade liberalization and wage inequality in Mexico. Industrial and Labor Relations Review, 52(2), 271-288.

Honaker, J., King, G., \& Blackwell, M. (2015). Package 'Amelia'. Retrieved from: http://cran.r-project. org/web/packages/Amelia/Amelia.pdf. Accessed 15 Nov 2016.

Howell, C. (2001). The end of the relationship between social democratic parties and trade unions? Studies in Political Economy, 65, 7-37.

Huber, E., \& Stephens, J. (2001). Development and crisis of the welfare state. Chicago: University of Chicago Press.

Hulme, M. H. (2016). Preambles in treaty interpretation. University of Pennsylvania Law Review, 164(5), 1281-1343.

International Labour Organisation. (2013). Social dimensions of free trade agreements. Geneva: International Institute for Labor Studies, ILO.

International Labour Organisation. (2016). Assessment of labour provisions in trade and investment arrangements. Geneva: ILO.

Kamata, I. (2016). Labor Clauses in Regional Trade Agreements and Effects on Labor Conditions: An Empirical Analysis. IDE discussion paper no. 609.

Katzenstein, P. (1985). Small states in world markets: Industrial policy in Europe. Ithaca: Cornell University Press. Kay, T. (2011). NAFTA and the politics of labor transnationalism. New York: Cambridge University Press.

Keck, M., \& Sikkink, K. (1998). Activists beyond borders: Advocacy networks in international politics. Ithaca: Cornell University Press.

Keefer, P. (2012). DPI2012 database of political institutions: Changes and variable definitions. World Bank.

Kerremans, B., \& Gistelinck, M. M. (2009). Interest aggregation, political parties, labour standards and trade: Differences in the US and EU approaches to the inclusion of labour standards in international trade agreements. European Foreign Affairs Review, 14, 683-701.

Kim, M. (2012). Ex ante due diligence: Formation of PTAs and protection of labor rights. International Studies Quarterly, 56(4), 704-719. 
Korpi, W. (1983). The democratic class struggle. London: Routledge and Kegan Paul.

Kucik, J. (2012). The domestic politics of institutional design: Producer preferences over trade agreement rules. Economics and Politics, 24(2), 95-118.

La Hovary, C. (2013). Showdown at the ILO? A historical perspective on the employers' Group's 2012 challenge to the right to strike. Industrial Law Journal, 42(4), 338-368.

Lechner, L. (2016). The domestic battle over the design of non-trade issues in preferential trade agreements. Review of International Political Economy, 23(5), 840-871.

Manger, M. (2009). Investing in protection: The politics of preferential trade agreements between north and south. Cambridge: Cambridge University Press.

Marshall, M., Gurr, T.R., \& Jaggers, K. (2016). Polity IV project: Political regime characteristics and transitions, 1800-2015.

Melitz, M. J. (2003). The impact of trade on intra- industry reallocations and aggregate industry productivity. Econometrica, 71(6), 1695-1725.

Milewicz, K., Hollway, J., Peacock, C., \& Snidal, D. (2016). Beyond trade: The expanding scope of the nontrade agenda in trade agreements. Journal of Conflict Resolution. https://doi.org/10.1177 /0022002716662687.

Milner, H. V., \& Judkins, B. (2004). Partisanship, trade policy, and globalization: Is there a left-right divide on trade policy? International Studies Quarterly, 48(1), 95-119.

Mishra, R. (1999). Globalization and the welfare state. Cheltenham: Edward Elgar.

Motta Veiga, P., \& Rios, S.P. (2008). Trade and development: The rising importance of sustainable development in the Latin American trade agenda. Brevissimos cindes 01. Center for Integration and Development Studies (CINDES), Rio de Janeiro, Brazil. http://www.cindesbrasil.org/site/index.php?option=com jdownloads\&Itemid=32\&view=finish\&cid=420\&catid=44. Accessed 26 Oct 2017.

Motta Veiga, P., \& Rios, S. P. (2009). Twenty-five years of trade policy in Brazil: Continuity and change. Center for Integration and Development Studies (CINDES), Rio de Janeiro, Brazil. Available at: $\mathrm{http} / /$ www.cindesbrasil.org/site/index.php?option=com_jdownloads\&Itemid=32\&view=finish\&cid=592 \&catid=44. Accessed 26 Oct 2017.

Novitz, T. (2012). The Committee of Experts and the right to strike: A historical perspective. International Union Rights, 19(2), 20-25.

Orbie, J., Van den Putte, L. \& Martens, D. (2017). The impact of labour rights commitments in EU trade agreements: The case of Peru. Politics and Governance, 5(4), 6-18.

Park, M. (2014). Trade liberalization and organized labour in the Asia-Pacific region: Barriers to labour internationalism. Globalizations, 11(1), 71-82.

Postnikov, E., \& Bastiaens, I. (2014). Does dialogue work? The effectiveness of labor standards in EU preferential trade agreements. Journal of European Public Policy, 21(6), 923-940.

Raess, D. \& Sari, D. (2017). Labor provisions in trade agreements (LABPTA): Introducing a new dataset. Available at: https://snis.ch/project/social-clause-through-back-door/. Accessed 20 Feb 2018.

Rodrik, D. (1997). Has globalization gone too far? Washington, D.C.: Institute for International Economics.

Rudra, N. (2002). Globalization and the decline of the welfare state in less-developed countries. International Organization, 56(2), 411-445.

Scheve, K., \& Slaughter, M. J. (2004). Economic insecurity and the globalization of production. American Journal of Political Science, 48(4), 662-674.

Smith, J. (2000). The politics of dispute settlement design: Explaining legalism in regional trade pacts. International Organization, 54(1), 137-180.

Spilker, G., \& Böhmelt, T. (2013). The impact of preferential trade agreements on governmental repression revisited. Review of International Organizations, 8, 343-361.

Van den Putte, L., \& Orbie, J. (2015). EU bilateral trade agreements and the surprising rise of labour provisions. The International Journal of Comparative Labour Law and Industrial Relations, 31(3), 263-284.

Van Roozendaal, G. 2002. Trade unions \& global governance: The debate on a social clause. London and New York: Continuum.

Visser, J. (2015). ICTWSS Data base. version 5.0. Amsterdam: Amsterdam Institute for Advanced Labour Studies AIAS.

Western, B. (1997). Between class and market: Postwar unionization in the capitalist democracies. Princeton: Princeton University Press. 